\title{
Regulation of Gene Expression in Downstream Signaling Molecules by Herbal Compound in Insulin Resistant Diabetic Rats
}

\author{
Aiman Abbas Jafri ${ }^{1}$, Suman Bala Sharma ${ }^{1 *}$, Kalpana Luthra ${ }^{2}$, Mohit Mehndiratta ${ }^{1}$, Nikhil Khurana ${ }^{1}$ and Usha Rani Singh ${ }^{3}$ \\ ${ }^{1}$ Department of Biochemistry, University College of Medical Sciences (University of Delhi), Dilshad Garden, Delhi, India \\ ${ }^{2}$ Department of Biochemistry, All India institute of Medical Sciences, Ansari Nagar, Delhi, India \\ ${ }^{3}$ Department of Pathology, University College of Medical Sciences (University of Delhi), Dilshad Garden, Delhi, India
}

*Corresponding author: Suman Bala Sharma, Director Professor Department of Biochemistry, University College of Medical Sciences, Dilshad Garden Delhi, India, Tel: +91-11-22592971; 919818041119; E-mail-drsbs08@hotmail.com

Rec date: 03 May 2017, Acc date: 29 June 2017, Pub date: 07 July 2017

Copyright: (C) 2017 Jafri AA, et al. This is an open-access article distributed under the terms of the Creative Commons Attribution License, which permits unrestricted use, distribution and reproduction in any medium, provided the original author and source are credited.

\begin{abstract}
Background: In previous studies, Sharma et al. has already isolated an anti-hyperglycemic compound from the fruit pulp of Eugenia jambolana using HPLC and other chromatographic techniques. However, the effect of antihyperglycemic compound (FIIc) on the expression of PPAR gamma, IRS-1 and IRS-2 in high sucrose diet induced type 2 diabetic rats has not been studied so far.

Methods: There were exactly 24 Male Wistar rats were taken and fed on High Sucrose Diet (HSD) for the development of type 2 diabetic animal for 30 weeks. Active compound Fllc was given to group $C$ and Pioglitazone to group $D$ at dose of $20 \mathrm{mg} / \mathrm{kg}$ of b.w. orally for 30 weeks respectively. Blood was drawn for the estimation of plasma glucose and serum insulin at week o and at week 30 from retro orbital plexus. At the end of the study animal were sacrificed and organs including pancreas and skeletal muscles were isolated and stored at $-80^{\circ} \mathrm{C}$. Total RNA was isolated by using Trizol method and expression of PPAR gamma, IRS-1 and IRS-2 was quantified and compared among the study groups by Real Time PCR.
\end{abstract}

Results: After treatment with Fllc for 30 weeks we found a significant reduction in post prandial blood glucose levels in group $C$ rats compared to group $B$. Serum insulin was also reduced in group $C$ rats compared to group $B$. In skeletal muscles the mRNA expression of PPAR $y$ and IRS-1 was found to be 2.48 fold and 2.56 fold increased respectively as compared to group B. Similarly the mRNA expression of IRS-2 in pancreas was found to be 2.69 folds increased as compared to group B.

Conclusion: Fllc treatment for 30 weeks improves glycemic control and insulin sensitivity by increasing the mRNA expression of PPAR $\mathrm{Y}$, IRS-1 and IRS-2.

Keywords: Eugenia jambolana; Type 2 diabetes; PPAR $\gamma$; IRS-1; IRS-2; Pioglitazone; Insulin resistance

Abbreviations PPAR $\gamma$ : Peroxisome Proliferator Activated Receptor Gamma; IRS: Insulin Receptor Substrate; HSD: High Sucrose Diet; IGF1: Insulin like Growth Factor-1; T2DM: Type 2 Diabetes Mellitus; b.w.: Body Weight, RXR: Retinoic X Receptor; PI3K: Phosphoinositide 3 kinase; HPLC: High Performance Liquid Chromatography; $\beta$ cell: Beta cell.

\section{Introduction}

Insulin resistance and beta cell failure are the hallmarks of type 2 diabetes [1,2] which appear to be genetically determined [3]. Insulin resistance is the first symptom of pathogenesis of diabetes which precedes the development of glucose intolerance. Initially, the pancreas increases the insulin secretion and production to compensate for hyperglycemia, and in due course of time it leads to beta cell failure [2].

Insulin initiates a wide variety of growth and metabolic effects by binding to the insulin receptor and activating its intrinsic tyrosine kinase. It causes phosphorylation on tyrosine residues of various downstream signaling molecules including insulin receptor substrate (IRS) proteins [4]. IRS molecules are key mediators in insulin signaling and play a central role in maintaining basic cellular functions such as growth, survival, and metabolism. They act as docking proteins between the insulin receptor and a complex network of intracellular signaling molecules $[5,6]$. Studies have shown that mice lacking IRS-1 exhibit retardation in embryonic and postnatal growth $[7,8]$ indicating that IRS-1 is important for growth-promoting effects of IGF-I. These mice also showed resistance to the glucose-lowering effects of insulin.

Similarly the IRS-2 is also a critical element in insulin-signaling pathways, and T2DM mice with the IRS-2 gene knocked out possess insulin resistance in the liver [9]. IRS-2 deficient mice became insulin resistant at 6 weeks, presumably because of insulin resistance in the liver and they progressively developed type 2 diabetes at 10 weeks [10]. Despite insulin resistance, the amount of beta cells was also found to be reduced to $83 \%$ of that of wild type mice, which was in marked contrast to the $85 \%$ increase in the amount of beta cells in IRS-1 deficient mice at 6 weeks. Thus, insulin resistance in liver combined with absence of compensatory beta cell hyperplasia caused type 2 diabetes in IRS-2 deficient mice [10]. These results suggest that IRS-1 
and IRS-2 may play different roles in the regulation of beta cell mass and function of individual beta cells.

On the other hand, PPAR $\gamma$ has been reported to be expressed in various tissues including adipose and skeletal muscles [11-13]. Studies have reported that PPAR $\gamma$ is a master regulator in the formation of fat cells and it plays an important regulatory role in adipocyte differentiation and metabolism [13]. Owing to their unique functions in regulating glucose, lipid and cholesterol metabolism, PPARs have drawn special attention for developing drugs to treat type- 2 diabetes. Increased serum levels of fatty acids and lipids have known to be associated with insulin resistance. The activation of PPAR $\gamma$ causes the uptake of lipids and fatty acids in fat depots and improves glycemic control and insulin sensitivity in peripheral tissues [13]. With the glycemic advantages of the PPAR- $\gamma$ agonists such as Thiazolidinediones (TZDs), the PPAR $\gamma$ agonists approach can improve the metabolic effects and minimize the side effects caused by either agent alone. Hence it has become a promising strategy for designing effective drugs against type- 2 diabetes.

Hence, this study was planned to establish a molecular mechanism of antihyperglycemic compound (FIIc) which was isolated from the fruit pulp of Eugenia jambolana in the previous studies by Sharma et al. [14] (US patent No. 6,428,825 August 2002; Indian Process patent no 188759 May 2003; Indian Product Patent no: 2, 30, 753 February 2009) by studying its effect on PPAR $\gamma$, IRS- 1 and IRS- 2 at mRNA level in HSD fed T2DM animal model. By determining its molecular mechanism we can predict its therapeutic targets and a novel approach for the treatment of diabetes.

\section{Material and Methods}

\section{Experimental animal model}

Male Wistar rats weighing $\approx 150-180$ grams were used as animal models of diabetes for the present study. The animals were procured from the central animal house, University College of Medical Sciences (UCMS), Delhi. The rats were fed on a standard chow diet (Hindustan Lever Ltd., Mumbai, India) and water ad libitum. The rats were housed under standard conditions of temperature $\left(22^{\circ} \mathrm{C} \pm 2^{\circ} \mathrm{C}\right)$ and 12 hour light dark cycle. For sacrificing animals $\mathrm{CO} 2$ inhalation was used.

\section{Induction of type 2 diabetes by feeding High Sucrose Diet}

The HSD as prepared by Madhu et al. [15] was used. It was prepared by mixing 12 liters of distilled water, $5.6 \mathrm{~kg}$ of chow diet, $1.8 \mathrm{~kg}$ of table sugar, $560 \mathrm{ml}$ of palm oil, $40 \mathrm{ml}$ of Vimeral, $40 \mathrm{ml}$ of calcium syrup and 160 grams of maize powder. The composition of high sucrose diet is carbohydrate $60 \%$ to $70 \%$ predominantly sucrose, fat $20 \%$ to $25 \%$ and protein $15 \%$ to $20 \%$. The prepared diet was kept at $4^{\circ} \mathrm{C}$.

\section{Methodology}

Exactly 24 Male Wistar rats were taken for the present study and given standard chow diet for 2 weeks. After 2 weeks of acclimatization, animals were randomized into 4 groups (6 rats per group).

- Group A: Healthy control given normal chow diet

- Group B: Diabetic control given HSD

- Group C: Diabetic treated with FIIc (20 mg/kg of body weight/day) given HSD
- Group D: Diabetic treated with Pioglitazone $(20 \mathrm{mg} / \mathrm{kg}$ of body weight/day) given HSD

Animals in group A were fed on normal chow diet whereas animals in group B, C and D were fed on High Sucrose Diet and water ad libitum throughout the study. Purified active compound FIIc and Pioglitazone were given orally to group $\mathrm{C}$ and group $\mathrm{D}$ orally, at a dose of $20 \mathrm{mg} / \mathrm{kg}$ of b.w./day for 30 weeks respectively. This is the effective dose standardized in previous studies done by Sharma et al. [14]. An equal volume of normal saline were given orally to group A and group $B$ rats.

At week 26 a mild dose of Streptozotocin at a dose of $15 \mathrm{mg} / \mathrm{kg}$ of body weight were given intraperitoneally to group B, group $\mathrm{C}$ and group $\mathrm{D}$ rats and were followed till week 30 . Blood was drawn from retro orbital plexus from overnight fasted animals on day 1 and afterwards at week 30 of the study. Blood/serum was collected for the estimation of glucose and insulin respectively. Fasting blood glucose and 2 hour post prandial blood glucose were estimated for the confirmation of diabetes. 2 hour post prandial blood glucose was estimated after giving a glucose load at a dose of $2 \mathrm{gm} / \mathrm{kg}$ of body weight in overnight fasted rats. At the end of $30^{\text {th }}$ week all the animals were sacrificed and their organs including skeletal muscles and pancreas were dissected out and stored at $-80^{\circ} \mathrm{C}$.

\section{RNA extraction by Trizol method}

The quantitative mRNA expression levels of PPAR $\gamma$, IRS- 1 were measured in skeletal muscles and IRS-2 was done in pancreatic tissues, depending upon their site of expression in the four study groups. At the end of the study, all the animals were sacrificed and the above mentioned tissues were dissected out and fixed in the Trizol reagent for extraction of RNA according to the manufacturer's protocols. $50 \mathrm{mg}$ to $100 \mathrm{mg}$ of tissue was taken and homogenized in $1 \mathrm{ml}$ of Trizol reagent using a plastic pestle or a sonicator (Thermo Scientific, USA). Sample was centrifuged at $12,000 \mathrm{~g}$ at $4^{\circ} \mathrm{C}$ for 10 minutes using a cooling centrifuge (Remi CPR 24, India). Pellets obtained were discarded and supernatant was transferred into another aliquot.

It was incubated at room temperature for 5 minutes. $200 \mu$ of biotechnology grade chloroform (Amresco, USA) was further added and incubated at room temperature for 15 mins. Again the sample was centrifuged at $12,000 \mathrm{~g} 15 \mathrm{mins}$ at $4^{\circ} \mathrm{C}$. The aqueous phase obtained after centrifugation was transferred in another aliquot and $0.5 \mathrm{ml}$ of biotechnology grade pure isopropanol was added to the aqueous phase. Sample was mixed by inverting the aliquot and incubated at room temperature for 10 mins.

The sample was again centrifuged at $12,000 \mathrm{~g}$ at $4^{\circ} \mathrm{C}$ for $10 \mathrm{~min}$. After centrifugation the supernatant was removed and pellets obtained was left intact. $1 \mathrm{ml}$ of biotechnology grade $75 \%$ ethanol was added and mixed properly by inverting the aliquot. The sample was again centrifuged at 7,500 g at $4^{\circ} \mathrm{C}$ for 5 minutes. The supernatant obtained was discarded and the aliquot was incubated on a dry bath at $57^{\circ} \mathrm{C}$ for 10 minutes.

After incubation $50 \mu \mathrm{l}$ of nuclease free water (Amresco, USA) was added and sample was put into $-20^{\circ} \mathrm{C}$ deep freezer. The quality of isolated RNA was determined spectrophotometrically $(260 / 280 \mathrm{~nm}$, 260/230 nm) using a Nano Drop (Thermo Scientific, Wilmington, DE, USA). The yield of RNA obtained was high and varied between 5000 $\mathrm{ng} / \mu \mathrm{l}$ to $6000 \mathrm{ng} / \mu \mathrm{l}$. 
Citation: Jafri AA, Sharma SB, Luthra K, Mehndiratta M, Khurana N, et al. (2017) Regulation of Gene Expression in Downstream Signaling Molecules by Herbal Compound in Insulin Resistant Diabetic Rats. Altern Integr Med 6: 243. doi:10.4172/2327-5162.1000243

Page 3 of 5

\section{cDNA preparation}

The RNA obtained from the tissues was used for the preparation of cDNA by using a First Strand cDNA synthesis kit (Thermo Scientific, Waltham, USA). After thawing and mixing the components of the kit properly, $1 \mu \mathrm{l}$ of sample RNA, $0.5 \mu$ of oligo dt primer and $0.5 \mu \mathrm{l}$ of random hexamer were mixed in $9 \mu$ of nuclease free water to make up the volume to $11 \mu \mathrm{l}$ and incubated on a dry bath at $65^{\circ} \mathrm{C}$ for 5 minutes. After incubation, $4 \mu \mathrm{l}$ of $5 \mathrm{X}$ reaction buffer, $1 \mu \mathrm{l}$ of RiboLock RNase inhibitor, $2 \mu \mathrm{l}$ of $10 \mathrm{mM}$ dNTP mix and $2 \mu \mathrm{l}$ of M-MuLV reverse transcriptase enzyme were added.

The master mix obtained was briefly centrifuged to remove any air bubbles and to bring any sample adhering at the walls to the bottom. This reaction mix was put for cDNA synthesis (Eppendorf master cycler nexus gradient, Eppendorf, Germany). The programming used was $25^{\circ} \mathrm{C}$ for 5 minutes, $45^{\circ} \mathrm{C}$ for 60 minutes, $70^{\circ} \mathrm{C}$ for 5 minutes and the reaction was put to end by bringing the reaction at $4^{\circ} \mathrm{C}$. The cDNA obtained was diluted by adding $60 \mu \mathrm{l}$ of nuclease free water and was stored in a $-80^{\circ} \mathrm{C}$ deep freezer.

\section{Real Time PCR Quantification}

The cDNA obtained was used as a sample for the determination of expression levels of PPAR $\gamma$, IRS-1 and IRS-2 by using Qiagen Thermal Cycler (Rotor-Gene Q 2plex+HRM System, Qiagen, USA) with Maxima SYBR Green/ROX qPCR Master mix (Thermo Scientific, USA). Alpha tubulin was used as an internal control gene.

- The primer sequences for PPAR $\gamma$, IRS-1, IRS-2 and alpha Tubulin were as follows

- PPAR $\gamma \quad$ Primer sequence- Fwd primer5'CCCTGGCAAAGCATTTGTAT 3, Rev Primer5'GGTGATTTGTCTGTTGTCTTTCC 3'

- IRS- 1 Primer sequence- Fwd Primer- 5' TCAACAGCAGTCCCTACCAC- 3', Rev Primer- 5'GCTGTGATGTCCAGTTACGC- 3'

- IRS- 2 Primer sequence- Fwd Primer- 5' TCCAGAACGGCCTCAACTAT- 3', Rev Primer- 5'AGTGATGGGACAGGAAGTCG- 3'

- Alpha tubulin Primer sequence- Fwd primer5'TAGCAGAGATCACCAATGCC 3', Rev Primer- 5' GGCAGCAAGCCATGTATTTA 3'

Real time PCR was conducted in a final volume of $20 \mu$ consisting of $10 \mu \mathrm{l}$ Maxima SYBR Green, $1 \mu \mathrm{l}$ forward primer $(10 \mathrm{mM}), 1 \mu \mathrm{l}$ reverse primer $(10 \mathrm{mM}), 3 \mu \mathrm{l} \mathrm{cDNA}$ sample and $5 \mu \mathrm{l}$ nuclease free water. The amplification parameters consisted of an initial activation at $95^{\circ} \mathrm{C}$ for 5 min followed by 40 cycles of a 3-step PCR (denaturation at $95^{\circ} \mathrm{C}$ for $15 \mathrm{sec}$, annealing at $52^{\circ} \mathrm{C}$ for $30 \mathrm{sec}$, and extension at $75^{\circ} \mathrm{C}$ for $30 \mathrm{sec}$ ). The PCR products formed was detected simultaneously and shown on the LCD display by measuring the increase in fluorescence caused by the binding of SYBR green dye into the major grooves of double helical DNA. The relative fold change in the mRNA expression levels of PPAR $\gamma$, IRS-1, IRS-2 and alpha Tubulin was calculated by the $2^{-\Delta \Delta C t}$ method as described by Schmittgen et al. [16]. The results were normalized to the mRNA expression level of alpha tubulin.

\section{Statistical analysis}

The statistical analysis was carried out by using analysis of variance (ANOVA) followed by tukeys test.

\section{Results}

As shown in Table 1, we observed a significant decrease in post prandial blood glucose levels in group $\mathrm{C}$ and group $\mathrm{D}$ rats compared to group B at week 30 after treatment with FIIc and Pioglitazone. However, no significant difference in fasting blood glucose levels was observed at week 0 among the four study groups.

At week 30 fasting serum insulin levels were also found to be decreased in group C and group D rats as compared to group B after treatment with FIIc and Pioglitazone. However this decrease is statistically not significant.

\begin{tabular}{|c|c|c|c|c|c|c|}
\hline Parameters & $\begin{array}{l}\text { Time } \\
\text { Points }\end{array}$ & $\begin{array}{l}\text { Group } \\
\text { A }\end{array}$ & $\begin{array}{l}\text { Group } \\
\text { B }\end{array}$ & $\begin{array}{l}\text { Group } \\
\text { C }\end{array}$ & $\begin{array}{l}\text { Group } \\
\text { D }\end{array}$ & p Value \\
\hline \multirow[t]{2}{*}{ FBG $(\mathrm{mg} / \mathrm{dl})$} & 0 Weeks & 86.5 & 85.5 & 84 & 84.33 & \multirow{2}{*}{$\begin{array}{l}a=0.0167 \\
b=0.1783 \\
c=0.5471\end{array}$} \\
\hline & 30 Weeks & 89.66 & $102.16 a$ & $93.16 \mathrm{~b}$ & $98.16 \mathrm{c}$ & \\
\hline \multirow{2}{*}{$\begin{array}{l}\text { PPBG } \\
(\mathrm{mg} / \mathrm{dl})\end{array}$} & 0 Weeks & 122.66 & 124.83 & 123.33 & 126.33 & \multirow{2}{*}{$\begin{array}{l}a=0.0001 \\
b=0.0007 \\
c=0.0001\end{array}$} \\
\hline & 30 Weeks & 136.83 & $236.83 a$ & $190.50 \mathrm{~b}$ & $183.33 c$ & \\
\hline \multirow{2}{*}{$\begin{array}{l}\text { Insulin } \\
(\mathrm{pmol})\end{array}$} & 0 Weeks & 13.16 & 14.66 & 14.75 & 14.32 & \multirow{2}{*}{$\begin{array}{l}a=0.003 \\
b=0.1411 \\
c=0.0631\end{array}$} \\
\hline & 30 Weeks & 15.71 & $29.71 \mathrm{a}$ & $23.88 \mathrm{~b}$ & $21.88 \mathrm{c}$ & \\
\hline
\end{tabular}

$\mathrm{a}=$ Healthy control $v s$. diabetic control, $\mathrm{b}=$ Diabetic control $v s$. diabetic treated with Fllc, c=Diabetic control vs. diabetic treated with Pioglitazone

Table 1: Showing Fasting blood glucose, post prandial blood glucose and serum Insulin levels at week 0 and at week 30 after treatment with FIIc and Pioglitazone.

In Figure 1, 2.4 and 3.53-fold increases in PPAR $r$ mRNA expression levels in skeletal muscles of groups $\mathrm{C}$ and $\mathrm{D}$ respectively were observed, when compared to group B after treatment with active herbal compound FIIc and Pioglitazone for 30 weeks.

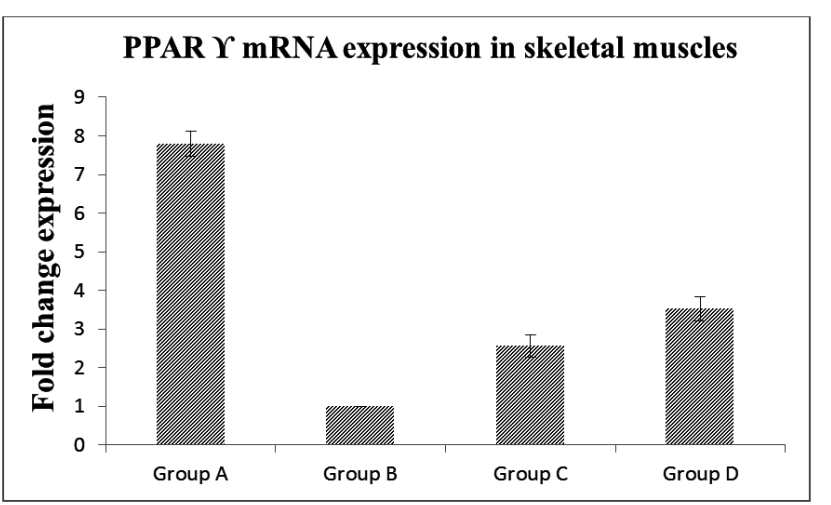

Figure 1: Showing PPAR $\gamma$ mRNA expression level in skeletal muscles at week 30 after treatments with FIIc and Pioglitazone.

In Figure 2, a 2.56 and 2.81 folds increase in IRS-1 mRNA expression level in skeletal muscles of group $\mathrm{C}$ and group $\mathrm{D}$ respectively was observed, when compared to group $\mathrm{B}$ after treatment with active herbal compound FIIc and Pioglitazone for 30 weeks. 


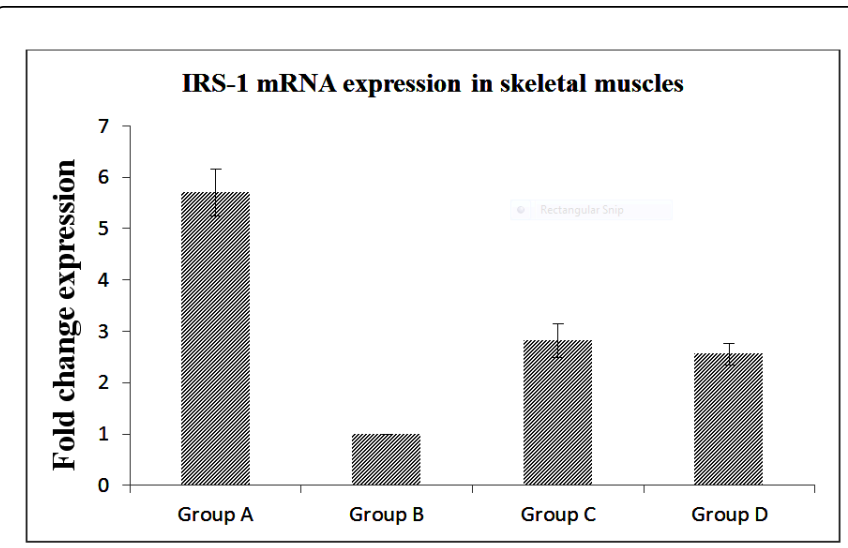

Figure 2: IRS-1 mRNA expression level after treatment with FIIc and Pioglitazone in skeletal muscles at week 30.

In Figure 3, a 2.69 and 2.05 folds increase in IRS-2 mRNA expression level in pancreas of group C and Group D respectively was observed, as compared to group B after treatment with active herbal compound FIIc and Pioglitazone for 30 weeks

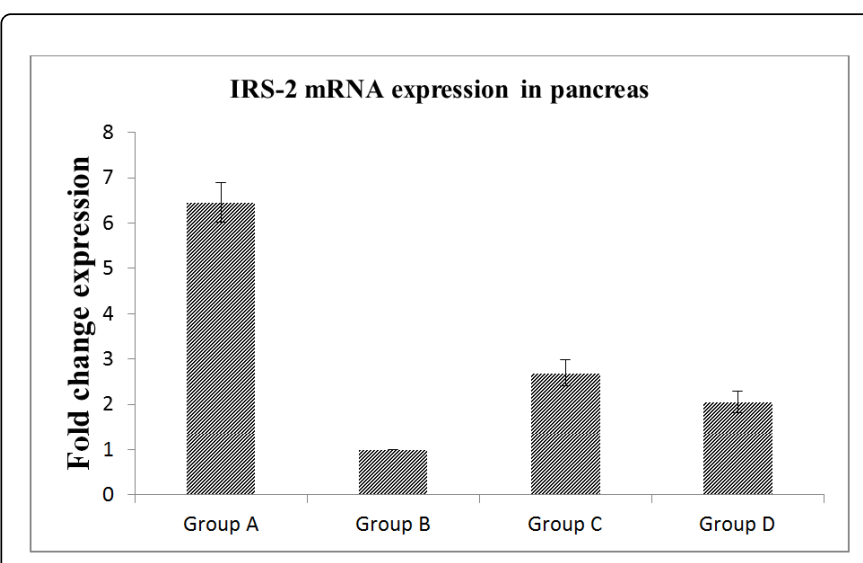

Figure 3: IRS-2 mRNA expression level after treatment with FIIc and Pioglitazone in pancreas at week 30.

\section{Discussion}

This study was conducted in HSD fed type 2 diabetic rats to study the effect of herbal anti-hyperglycemic compound (FIIc) on peripheral insulin sensitivity by measuring the mRNA expression levels of PPAR $\gamma$, IRS-1 and IRS-2. After treatment with FIIc at week 30, we observed a 2.48 and 2.56 folds increase in PPAR $\gamma$ and IRS-1 mRNA expression level in skeletal muscles of group C as compared to group B. Similarly, a 2.69 folds increase in IRS-2 mRNA expression level in pancreas of group $\mathrm{C}$ was observed, as compared to group B. A significant fall in post prandial blood glucose levels was also observed in group $\mathrm{C}$ and Group D rats as compared to group B. serum insulin was also found to be reduced in group $\mathrm{C}$ as compared to group $\mathrm{B}$ as an indicator of reduced insulin resistance upon treatment with FIIc for 30 weeks.

Insulin resistance is a characteristic feature of type 2 diabetes in which a higher than normal levels of insulin is required for maintaining normal glucose levels. Various studies have reported that
PPAR $\gamma$ is down regulated in type 2 diabetes and insulin resistant states and up regulation of PPAR $\gamma$ upon binding of the synthetic PPAR $\gamma$ ligands in T2DM results in a marked improvement in whole body insulin sensitivity and improved glycaemic control [13,17-19]. Similarly, studies have also reported that IRS- 1 is an important element in insulin signaling pathways and defect in the IRS-1 gene has been reported to be associated in the generation of T2DM [20,21]. Literature survey has also reported a significantly reduced IRS-1 mRNA levels in obese subjects and insulin resistant subjects compared with healthy lean and insulin sensitive subjects [22]. Hence, above studies showed that IRS-1 plays an important role in the susceptibility to type 2 diabetes. Similarly IRS-2 is also an important player in insulin-signaling pathways. Genetic studies have also reported that IRS-2 knockout resulted in the development of insulin resistance in the liver and type 2 diabetes [9-10,23-24].

When insulin binds to cell surface receptors it initiates a cascade of events by activating the intra cellular tyrosine kinase domain of $\beta$ subunit which leads to a rapid auto phosphorylation of downstream signaling molecules such as IRS-1, IRS-2 and several Shc proteins which in turn activates further intracellular signaling intermediates [25] hence leads to uptake of glucose, lipids and other metabolites. We strongly suggested that cause of insulin resistance lies at the post receptor level of insulin signaling. Thus, various studies in the past failed to explain a normal or slightly reduced insulin receptor tyrosine kinase activity in insulin resistance subjects, in spite for a substantial reductionin insulin action [26].

In a recent study it has been reported that upon treatment with a Chinese herbal traditional medicine (a partial PPAR $\gamma$ agonist) prevented hyperglycaemia and weight gain in vivo [27]. Studies have also reported that herbal drugs were found to be useful in improving the mRNA expression of IRS-1 [28,29] and IRS-2 in type 2 diabetes $[30,31]$. The possible mechanism of FIIc through which it improves the PPAR $\gamma$ mRNA expression is through the binding of retinoic $\mathrm{X}$ receptor (RXR) present on the DNA. Upon binding it causes corepressor release and co-activator binding and resulting in increased affinity for the specific PPAR response element, which modulates gene transcription.

Similarly, In a recent study it has been reported that upon treatment with herbal traditional Chinese medicine in T2DM, resulted in significantly increased expression of IRS-1, PI3K and other downstream signaling molecules suggesting an effective herbal therapy for insulin resistance by regulating the PI3K/Akt signaling pathway in adipose tissues [32]. During insulin signaling pathway, the activation of PI3K phosphorylates Akt, which further activates the downstream signaling molecules and mediates glucose uptake and intracellular glycogen synthesis in skeletal muscle. In our study we also observed a similar finding suggesting that this might be the possible mechanism of action of our herbal active compound FIIc.

Animal studies have also reported that down regulation of IRS-2 causes peripheral insulin resistance leading to $\beta$ cell failure and T2DM $[9,10,34]$ and up-regulation of IRS-2 in $\beta$ cells leads to improved glucose tolerance and prevents diabetes in IRS-2 deficient and obese mice [33]. Increased serum insulin and IGF1 levels activates Akt pathway is also an important factor for the up regulation of IRS-2. In our study we have observed decreased serum insulin levels and increased mRNA expression levels of IRS-2 at week 30 of the study. Hence our results are in accordance with the previous studies and this might be the possible mechanism of action of FIIc in regulation of insulin signaling mechanism in improving glycemic control. 
Citation: Jafri AA, Sharma SB, Luthra K, Mehndiratta M, Khurana N, et al. (2017) Regulation of Gene Expression in Downstream Signaling Molecules by Herbal Compound in Insulin Resistant Diabetic Rats. Altern Integr Med 6: 243. doi:10.4172/2327-5162.1000243

Page 5 of 5

\section{Acknowledgements}

The authors acknowledge Indian Council of Medical Research, Ansari Nagar, New Delhi for their financial support.

\section{References}

1. Marlon EC (2013) Beta cell dysfunction and insulin resistance. Front Endocrinol (Lausanne) 4: 37.

2. Sesti G, Federici M, Hribal ML, Lauro D, Sbraccia P, et al. (2001) Defects of the insulin receptor substrate (IRS) system in human metabolic disorders. Faseb J 15: 2099-2111.

3. De Fronzo RA (1997) Pathogenesis of Type 2 diabetes: Metabolic and molecular implications for identifying diabetes genes. Diabetes Rev 5: 177-269.

4. White MF (1997) The insulin signaling system and the IRS proteins. Diabetologia. 40: S2-S17.

5. Rondinone CM, Wang LM, Lonnroth P, Wesslau C, Pierce JH, et al. (1997) Insulin receptor substrate (IRS) 1 is reduced and IRS-2 is the main docking protein for phosphatidylinositol 3-kinase in adipocytes from subjects with non-insulin-dependent diabetes mellitus. Proc Natl Acad Sci 94: 4171-4175.

6. Bunner AE, Chandrasekera PC, Barnard ND (2014) Knockout mouse models of insulin signaling: Relevance past and future. World J Diabetes. 5:146-159.

7. Araki E, Lipes MA, Patti ME, Brüning JC, Haag B, et al. (1994) Alternative pathways of insulin signaling in mice with targeted disruption of the IRS-1 gene. Nature 372: 186-190.

8. Tamemoto H, Kadowaki T, Tobe K, Yagi T, Sakura H, et al. (1994) Insulin resistance and growth retardation in mice lacking insulin receptor substrate-1. Nature 372: 182-186.

9. Withers DJ, Gutierrez JS, Towery H, Burks DJ, Ren JM, et al. (1998) Disruption of IRS-2 causes type 2 diabetes in mice. Nature. 391: 900-904.

10. Kubota N, Tobe K, Terauchi Y, Eto K, Yamauchi T, et al. (2000) Disruption of insulin receptor substrate 2 causes type 2 diabetes because of liver insulin resistance and lack of compensatory beta-cell hyperplasia. Diabetes. 49: 1880-1889.

11. Grygiel-Górniak B (2014) Peroxisome proliferator-activated receptors and their ligands: nutritional and clinical implications-a review. Nutr J 14: 13:17.

12. Ji S, Yang R, Lu C, Qiu Z, Yan C, et al. (2014) Differential expression of PPAR $\gamma$, FASN, and ACADM genes in various adipose tissues and longissimusdorsi muscle from yanbian yellow cattle and yan yellow cattle. Asian-Australas J Anim Sci 27: 10-18.

13. Wang YX. PPARs (2010) Diverse regulators in energy metabolism and metabolic diseases. Cell Res 20: 124-137.

14. Tanwar RS, Sharma SB, Singh UR, Prabhu KM (2011) Antiatherosclerotic potential of active principle isolated from Eugenia jambolana in streptozotocin-induced diabetic rats. Evid Based Complement Alternat Med 2011: 127641.

15. Madhu SV, Aslam M, Galav V, Bhattacharya SK, Aiman AJ (2014) Atorvastatin prevents type 2 diabetes mellitus- an experimental study. Eur J Pharmacol. 728: 135-140.
16. Schmittgen TD, Livak KJ (2008) Analyzing real-time PCR data by the comparative CT method. Nature Protocols. 3: 1101-1108

17. Bermúdez V, Finol F, Parra N, Parra M, Pérez A, et al. (2010) PPAR- $\gamma$ agonists and their role in type 2 diabetes mellitus management. Am J Ther 17: 274-283.

18. Lecarpentier Y, Claes V, Vallée A, Hébert JL (2017) Interactions between PPAR gamma and the Canonical Wnt/Beta-Catenin pathway in type 2 diabetes and colon cancer. PPAR Res 5879090.

19. Larsen TM, Toubro S, Astrup A (2003) PPAR $\gamma$ agonists in the treatment of type II diabetes: Is increased fatness commensurate with long-term efficacy? IntJ Obes Relat Metab Disord 27: 147-161.

20. Carvalho E, Jansson PA, Axelsen M, Eriksson JW, Huang X, et al. (1999) Low cellular IRS 1 gene and protein expression predict insulin resistance and NIDDM. FASEB J. 13: 2173-2178.

21. Aytug S, Reich D, Sapiro LE, Bernstein D, Begum N (2003) Impaired IRS-1/PI3-kinase signaling in patients with HCV: A mechanism for increased prevalence of type 2 diabetes. Hepatology 38: 1384-1392.

22. Kovacs P, Hanson RL, Lee YH, Yang X, Kobes S, et al. (2003) The role of insulin receptor substrate-1 gene (IRS1) in type 2 diabetes in Pima Indians. Diabetes. 52: 3005-3009.

23. Brady MJ (2004) IRS2 takes center stage in the development of type 2 diabetes. J Clin Invest 114: 886-888.

24. Taniguchi CM, Ueki K, Kahn CR (2016) Complementary roles of IRS-1 and IRS-2 in the hepatic regulation of metabolism. J Clin Invest 126: 4387.

25. Boucher J, Kleinridders A, Kahn RC (2014) Insulin Receptor Signaling in Normal and Insulin-Resistant States. Cold Spring Harb Perspect Biol. 6: a009191.

26. Draznin B (2006) Molecular mechanisms of insulin resistance: serine phosphorylation of insulin receptor substrate-1 and increased expression of p85alpha: The two sides of a coin. Diabetes. 55: 2392-2397.

27. Atanasov AG, Wang JN, Gu SP, Bu J, Kramer MP, et al. (2013) Honokiol: A non-adipogenic PPAR $\gamma$ agonist from nature. Biochim Biophys Acta 1830: 4813-4319.

28. Hu X, Wang M, Bei W, Han Z, Guo J (2014) The Chinese herbal medicine FTZ attenuates insulin resistance via IRS1 and PI3K in vitro and in rats with metabolic syndrome. J Transl Med 12: 47.

29. Yang L, Wang Z, Jiang L, Sun W, Fan Q, et. al. (2017) Total flavonoids extracted from oxytropisfalcata bunge improve insulin resistance through regulation on the $\mathrm{ikk} \beta / \mathrm{nf}-\kappa \mathrm{b}$ inflammatory pathway. Evid Based Complement Alternat Med 2405124.

30. Kuznetsova A, Yu Y, Hollister-Lock J, Opare-Addo L, Rozzo A, et al. (2016) Trimeprazine increases IRS2 in human islets and promotes pancreatic $\beta$ cell growth and function in mice. JCI Insight 1: e80749.

31. Hennige AM, Burks DJ, Ozcan U, Kulkarni RN, Ye J, et al. (2003) Up regulation of insulin receptor substrate- 2 in pancreatic beta cells prevents diabetes. J Clin Invest 112: 1521-1532.

32. Lin X, Taguchi A, Park S, Kushner JA, Li F, et al. (2004) Dysregulation of insulin receptor substrate 2 in beta cells and brain causes obesity and diabetes. J Clin Invest 114: 908-916.

33. Hennique AM, burks DJ, Ozcan U, Kulkarni RN, Park S, et al. (2003) Up regulation of insulin receptor substrate-2 in pancreatic beta cells prevents diabetes. J Clin Invest. 112: 1521-1532 